\title{
Ensemble analysis of frost damage on vegetation caused by spring backlashes in a warmer Europe
}

\author{
A. M. Jönsson ${ }^{1}$ and L. Bärring ${ }^{2}$ \\ ${ }^{1}$ Department of Physical Geography and Ecosystems Analysis, Geobiosphere Science Centre, Lund University, \\ Sölvegatan 12, 22362 Lund, Sweden \\ ${ }^{2}$ Rossby Centre, Swedish Meteorological and Hydrological Institute, 601 76, Norrköping, Sweden
}

Received: 22 January 2010 - Revised: 21 December 2010 - Accepted: 18 January 2011 - Published: 10 February 2011

\begin{abstract}
Tree dehardening and budburst will occur earlier in a warmer climate, and this could lead to an increased risk of frost damage caused by temperature backlashes. By using a spring backlash index and a cold hardiness model, we assessed different aspects of risk for frost damage in Norway spruce forests during the present climate and for one future emission scenario. Uncertainties associated with climate modelling were quantified by using temperature data from three climate data sets: (1) E-Obs gridded observed climate data, (2) an ensemble of data from eight regional climate models (RCM) forced by ERA-40 reanalysis data, (3) an ensemble of regional climate scenarios produced by the regional climate model RCA3 driven at the boundary conditions by seven global climate models (GCM), all representing the SRES A1B emission scenario.
\end{abstract}

The frost risk was analysed for three periods, 1961-1990, 2011-2040 and 2070-2097. The RCA3_GCM ensemble indicated that the risk for spring frost damage may increase in the boreo-nemoral forest zone of southern Scandinavia and the Baltic states/Belarus. This is due to an increased frequency of backlashes, lower freezing temperatures after the onset of the vegetation period and the last spring frost occurring when the trees are closer to budburst. The changes could be transient due to the fine balance between an increased risk of frost damage caused by dehardening during a period when freezing temperatures are common and a decreased risk caused by warmer temperatures. In the nemoral zone, the zone with highest risk for spring backlashes during the reference period (1961-1990), the spring frost severity may increase due to frost events occurring when the trees are closer to budburst. However, the risk in terms of frequency of backlashes and freezing temperature were projected to become lower already in the beginning of this century.

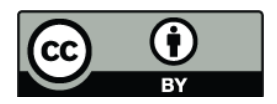

Correspondence to: A. M. Jönsson (anna_maria.jonsson@nateko.lu.se)

\section{Introduction}

Annual mean temperature and precipitation influences the large-scale distribution of terrestrial biomes. Extreme weather events such as drought, storm and frost, can have a large impact on plant species composition at finer scales thought the differential effects on competition among species. Climate change is likely to alter the temperature and precipitation regimes in northern Europe, including the frequency and severity of extreme events (Schär et al., 2004; Good et al., 2006; IPCC, 2007; Nikulin et al., 2011). Such changes may have consequences for both natural and managed ecosystems (Gutschick and BassiriRad, 2003). The positive effects of increased warmth and growing season length can lead to increased wood production (Bergh et al., 2003); however, adaptation in current forest management regimes is likely to be required to reduce the risk of damage caused by extreme weather events and to preserve biodiversity (SOU, 2007).

An earlier timing of spring phenology has been observed in response to the increase in temperature during the last decades (IPCC, 2007), including effects on timing of leafing and flowering (Menzel, 2006; Linkosalo et al., 2009). Leafing and flowering are preceded by physiological processes associated with winter dormancy and tolerance of low winter temperatures. A cumulative impact of ambient temperature influences the development of cold hardiness, as well as spring dehardening (Kalberer et al., 2006). In a warmer climate, the trees may not develop maximum cold hardiness and they may be hardened for a shorter period of time (cf. Eriksson, 2007; Hänninen and Kramer, 2007; Hänninen et al., 2001; Kozlowski and Pallardy, 2002; Kullman, 1997; Saxe et al., 2001 for literature reviews covering this topic). An earlier onset of spring phenology has raised concern about an increased risk of frost damage, as this may occur already in the beginning of the year when the seasonal temperature progression is slow and the risk of temperature backlashes

Published by Copernicus Publications on behalf of the European Geosciences Union. 
with sudden frost episodes is high (Myking, 1997; Jönsson et al., 2004; Cannell and Smith, 1986). The main reason for this is the higher incidence of cold air masses, as well as more extensive radiative cooling under cloud-free situations during the longer nights early in the year. Temperatures below the hardiness level will cause frost damage to shoots, cambium and roots. In particular, trees are very vulnerable during budburst (Kozlowski and Pallardy, 2002; Augspurger, 2009). Frost damage can cause a substantial economic loss due to lowered timber quality and reduced tree growth. Repeated climatic stress decreases the resistance and resilience against other stress factors (Larsen, 1995).

Norway spruce (Picea abies (L.) H. Karst) is one of the dominating tree species in the boreal forest of northern Europe and in continental parts of central Europe. As a genetic adaptation to the local climate, the thermal requirement for reaching budburst differs between different provenances, i.e. spruce trees from different regions (Hannerz, 1994; Sogaard, 2008). In general, spruce trees from central Europe require a higher accumulated thermal sum (degreedays) before budburst compared to spruce trees in northern Europe (Hannerz, 1994), as the fast seasonal temperature progression in the north lowers the risk for spring backlashes. Changes in timing of dehardening and budburst and the associated risk for damage will have implications for forest management practices, in particular during the phase of forest regeneration with selection of suitable tree species and provenances (Eriksson, 2007).

The aim of this study is to evaluate the effect of climate change on the risk for spring frost damage in European forests situated north of the Alps, where Norway spruce (Picea abies) is a common species in managed forests. We will use two impact models (Jönsson et al., 2004) to test the hypothesis that the risk for spring frosts will increase in a warmer climate due to earlier onset of the vegetation period: (A) a spring backlash index (SBI) model, and (B) a cold hardiness model (CHM). The principal difference between the two models is that the SBI measures the impact of freezing events below a fixed threshold after the onset of the vegetation period without taking the hardening level of the trees into account, and the CHM focuses on the impact of cold events in relation to a seasonally accumulated hardiness level of the trees. The impact models will be driven by three climate data sets: (1) gridded observed climate data, (2) reanalysis data downscaled by an ensemble of eight regional climate models, (3) an ensemble of data from one regional climate model, RCA3, driven at the boundary conditions by seven global climate models, all representing the SRES A1B emission scenario (Nakićenović and Swart, 2000) for the 21 st century. The two impact models will be run with climate data from the different ensemble members and the results will be compared to assess uncertainties related to climate modelling.

\section{Material and methods}

\subsection{Spring backlash index (SBI) model}

For Norway spruce, the onset of spring recovery starts approximately after four to five consecutive days with a mean temperature above $5^{\circ} \mathrm{C}$ (Suni et al., 2003). The accumulation of degree-days can be used as an indirect measurement of dehardening processes, expressing the potential severity of a late spring frost (Lindergård, 1996). The spring backlash index (sbi) was calculated according to Jönsson et al. (2004):

$\mathrm{sbi}=\sum_{i=a}^{b} \max \left(\mathrm{T}^{2} \operatorname{mean}_{i}-5,0\right)$

where T2mean is daily mean temperature at $2 \mathrm{~m}$ above ground, $i$ is an index for day number, $a$ is the first day of the vegetation period which is defined as 4 consecutive days with T2mean $>5^{\circ} \mathrm{C}$, and $b$ is the last cold event during spring, i.e. the last day $(a<b \leq 180)$ having T $2 \min <-2{ }^{\circ} \mathrm{C}$. Four measures were derived from this index (Table 1), giving complementary information on the risk for spring frost damage. The spring backlash index provides a measure of damage severity; a higher index indicates that the vegetation is more vulnerable to frost damage as it has reached more advanced spring phenological stages. The frequency and severity of potentially harmful frost events are indicated by the number of spring backlashes and the lowest freezing temperature. The combination of these two measurements is useful for evaluating uncertainties associated with climate model data. The spring frost events are calculated between the onset of the vegetation period and the end of June (day 180). However, the onset of the vegetation period can occur very late at high altitudes/latitudes, in regions (single gridcells) having a very harsh climate with short vegetation period. If a frost event occurs after the beginning of July, it will not be calculated as a spring frost event according to the above definition.

\subsection{Cold hardiness model (CHM)}

The seasonal development of cold hardiness and the onset of dehardening was modelled according to Jönsson et al. (2004). The cold hardiness level was calculated with a daily time step. For each time step, the daily mean temperature was used for calculating a steady-state hardiness level, with a minimum cold hardiness level of $-2{ }^{\circ} \mathrm{C}$ and a maximum cold hardiness level of $-50^{\circ} \mathrm{C}$ (Fig. 1a). The steadystate hardiness level corresponds to a threshold of frost tolerance induced by temperature dependent chemical reactions and cellular adjustments to withstand freezing temperatures. For each time step, the steady-state hardiness level was compared with the cold hardiness level of the day before. If the cold hardiness level was above the steady-state hardiness level, it was changed according to a temperature dependent daily hardening rate (Fig. 1b). If the cold hardiness level was below the steady-state hardiness level, the cold 

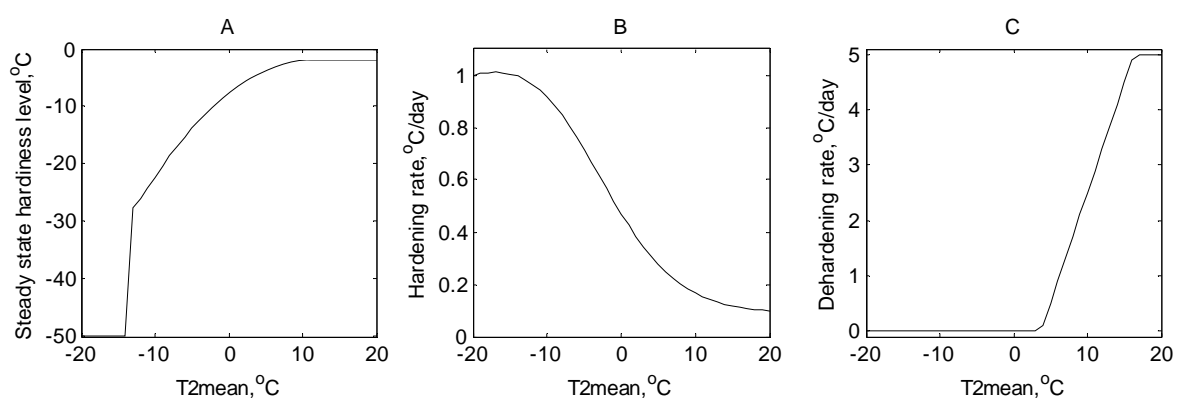

Fig. 1. Relations between daily mean temperature and (A) desired hardiness level, (B) hardening rate and (C) dehardening rate, used for calculating the seasonal changes in cold hardness level.

Table 1. Seven measures for assessing the severity of spring frost events were derived from a spring backlash index (SBI) and a cold hardiness model (CHM). Climate model data (Table 2) was used for calculating weather impact on the measured processes.

\begin{tabular}{|c|c|c|c|}
\hline Model & Process & Weather impact & Output from impact model \\
\hline SBI & $\begin{array}{l}\text { Start of dehardening/ } \\
\text { vegetation period }\end{array}$ & $\begin{array}{l}4 \text { consecutive days with } \\
\mathrm{T} 2 \text { mean }>+5^{\circ} \mathrm{C} \\
\text { (i.e. variable } a \text { in Eq. } 1 \text { ) }\end{array}$ & $\begin{array}{l}\text { Date } \\
\text { [Julian day number] }\end{array}$ \\
\hline SBI & $\begin{array}{l}\text { Spring backlash with } \\
\text { latest frost damage }\end{array}$ & $\begin{array}{l}\text { The temperature sum accumulated } \\
\text { between the start of dehardning and } \\
\text { the last day with } \mathrm{T} 2 \mathrm{~min}<-2{ }^{\circ} \mathrm{C} \text {, } \\
\text { (i.e. variable } b \text { in Eq. } 1 \text { ) }\end{array}$ & $\begin{array}{l}\text { Spring backlash index } \\
\text { [degree-days] }\end{array}$ \\
\hline SBI & $\begin{array}{l}\text { Number of spring } \\
\text { backlash events }\end{array}$ & $\begin{array}{l}\text { Number of days where } \mathrm{T} 2 \mathrm{~min}<-2{ }^{\circ} \mathrm{C} \\
\text { after start of dehardning and before } \\
\text { the end of the season (day 180) }\end{array}$ & $\begin{array}{l}\text { Total number of events } \\
\text { during the first half of the year }\end{array}$ \\
\hline SBI & $\begin{array}{l}\text { Lowest temperature } \\
\text { during a backlash event }\end{array}$ & $\begin{array}{l}\text { Minimum T2min after } \\
\text { start of dehardening }\end{array}$ & $\begin{array}{l}\text { Minimum temperature } \\
{\left[{ }^{\circ} \mathrm{C}\right]}\end{array}$ \\
\hline $\mathrm{CHM}$ & $\begin{array}{l}\text { Maximum cold } \\
\text { hardiness level }\end{array}$ & $\begin{array}{l}\text { Integrated seasonal tree hardiness } \\
\text { derived from daily } \mathrm{T} 2 \mathrm{mean}\end{array}$ & $\begin{array}{l}\text { Hardiness level } \\
{\left[{ }^{\circ} \mathrm{C}\right]}\end{array}$ \\
\hline $\mathrm{CHM}$ & $\begin{array}{l}\text { Maximum frost } \\
\text { damage }\end{array}$ & $\begin{array}{l}\text { Maximum negative temperature } \\
\text { difference (T2min - cold hardiness level) } \\
\text { for events where } \mathrm{T} 2 \mathrm{~min}<\text { daily cold hardiness level) }\end{array}$ & $\begin{array}{l}\text { Frost severity } \\
\text { (temperature difference) }\left[{ }^{\circ} \mathrm{C}\right]\end{array}$ \\
\hline $\mathrm{CHM}$ & $\begin{array}{l}\text { Number of damaging } \\
\text { frost events }\end{array}$ & $\begin{array}{l}\text { T2min }<\text { daily cold hardiness level } \\
\text { (day } 1-180)\end{array}$ & $\begin{array}{l}\text { Total number of events } \\
\text { per spring }\end{array}$ \\
\hline
\end{tabular}

hardiness level was adjusted according to a temperature dependent de-hardening rate (Fig. 1c). However, dehardening was not calculated between the autumn equinox (day 260) and the winter solstice (day 355), accounting for those mild periods before the winter solstice does not induce ontogenetic development toward bud burst (Partanen et al., 1998). Three measures providing complementary information were derived from this model (Table 1).

\subsection{Climate datasets}

Three different climate datasets were used in this study, all having a spatial resolution of approximately $50 \times 50 \mathrm{~km}$, i.e. 0.44 degree latitude/longitude in a rotated pole coordinate system: (1) The E-Obs gridded European weather dataset covering the period 1961-1990 (Haylock et al., 2008) available through the URL http://eca.knmi.nl/ensembles. This dataset is based on a large number of daily meteorological observations that were gridded by means of statistical interpolation techniques to produce both a best estimate and an upper and lower 95\% confidence bound for each gridcell and day, accounting for the variability in the data from the individual stations. Consequently, this dataset not only provides gridded best estimates of the climatic conditions in each gridcell but also information on the uncertainty range inherent in observations of the climatic conditions. It was used for evaluation purposes because it 
Table 2. List of climate data used in this study. For brevity, shorthand model names were used in the text and figures.

\begin{tabular}{|c|c|c|}
\hline $\begin{array}{l}\text { E-Obs } \\
\text { (Haylock et al., 2008) }\end{array}$ & RCM_ERA40 ensemble & $\begin{array}{l}\text { RCA3_GCM ensemble } \\
\text { (Kjellström et al., 2011) }\end{array}$ \\
\hline lower $95 \%$ confidence bound & $\begin{array}{l}\text { DMI-HIRHAM } \\
\text { (Christensen et al., 1996) }\end{array}$ & $\begin{array}{l}\text { HADCM3-Q0 (ref) } \\
\text { (Gordon et al., 2000; } \\
\text { Collins et al., 2006a) }\end{array}$ \\
\hline best estimate & $\begin{array}{l}\text { ETHZ-CLM } \\
\text { (Böhm et al., 2006) }\end{array}$ & $\begin{array}{l}\text { HADCM3-Q16 (high) } \\
\text { (Gordon et al., 2000; } \\
\text { Collins et al., 2006a) }\end{array}$ \\
\hline \multirow[t]{6}{*}{ upper $95 \%$ confidence bound } & $\begin{array}{l}\text { KNMI-RACMO2 } \\
\text { (van Meijgaard et al., 2008) }\end{array}$ & $\begin{array}{l}\text { HADCM3-Q3 (low) } \\
\text { (Gordon et al., 2000; } \\
\text { Collins et al., 2006a) }\end{array}$ \\
\hline & $\begin{array}{l}\text { METNO-HIRHAM } \\
\text { (Christensen et al., 1996; } \\
\text { Haugen and Haakenstad, 2006) }\end{array}$ & $\begin{array}{l}\text { ECHAM5/MPI-OM } \\
\text { (Roeckner et al., 2006; } \\
\text { Jungclaus et al., 2006) }\end{array}$ \\
\hline & $\begin{array}{l}\text { METO-HC_HadRM3.0 } \\
\text { (Buonomo et al., 2007) }\end{array}$ & $\begin{array}{l}\text { BCCR-BCM } \\
\text { (Bleck et al., 1992; } \\
\text { Déqué et al., 1994) }\end{array}$ \\
\hline & $\begin{array}{l}\text { MPI-M-REMO } \\
\text { (Jacob, 2001; Jacob et al., 2001) }\end{array}$ & $\begin{array}{l}\text { CCSM3 } \\
\text { (Collins et al., 2006b) }\end{array}$ \\
\hline & $\begin{array}{l}\text { RCA3 } \\
\text { (Kjellström et al., 2005) }\end{array}$ & $\begin{array}{l}\text { CNRM-CM3 } \\
\text { (Déqué et al., 1994; } \\
\text { Royer et al., 2002) }\end{array}$ \\
\hline & $\begin{array}{l}\text { GKSS-CLM } \\
\text { (Böhm et al., 2006) }\end{array}$ & \\
\hline
\end{tabular}

is fully independent of climate models. (2) An ensemble (Christensen et al., 2009) of data from eight different regional climate models (Table 2) has been forced by the ERA40 reanalysis data (Uppala et al., 2005). This ensemble, herein denoted RCM_ERA40, was developed within the ENSEMBLES project and is available through the ENSEMBLES data archive (URL: http://ensemblesrt3.dmi.dk/). RCA3 (Kjellström et al., 2005; Samuelsson et al., 2011) is one of the regional climate models in this ensemble, and this specific run is denoted RCA3_ERA40 in the following. (3) An ensemble (Kjellström et al., 2011) of regional climate scenarios comprising data from runs with RCA3 forced at the lateral boundaries by seven different GCM runs representing the SRES A1B climate change scenario (Nakićenović and Swart, 2000). For the purpose of this paper, the ensemble is denoted RCA3_GCM (Table 2). In our analyses, this dataset was divided into three periods: 1961-1990, 20112040 and 2070-2097. The two first periods cover 30 years each, whereas the last period only comprises 28 years because for some model runs, data were not available up to and including the year 2100 .

\subsection{Overview of the simulation and evaluation strategy}

The SBI and CHM impact models were run for all data series/ensemble members listed in Table 2, thus producing (i) the SBI E-Obs and CHM E-Obs dataset (three series each), (ii) the SBI/CHM RCM_ERA40 ensemble (eight series each), and (iii) the SBI/CHM RCA3_GCM ensemble (seven series each). The reference period 1961-1990 is common to all data series. Firstly, by comparing SBI/CHM EObs and SBI/CHM RCM_ERA40 we illustrate how the observational uncertainty (quantified by the E-Obs lower and upper $95 \%$ confidence limits) is carried over to the impact model output, and how this uncertainty compares to the variation in the impact model output produced by the RCM_ERA40 ensemble. Secondly, by analysing the two SBI/CHM RCM_ERA40 ensembles and in particular look at how the SBI/CHM RCA3_ERA40 runs compares to the other ensemble members we establish the basis for putting the climate change simulations into the context of the larger RCM ensemble. Thirdly, a comparison of the SBI/CHM RCA3_ERA40 output and the SBI/CHM RCA3_GCM ensemble reference period allows assessment of the effect of differences among the forcing GCMs on the SBI/CHM 


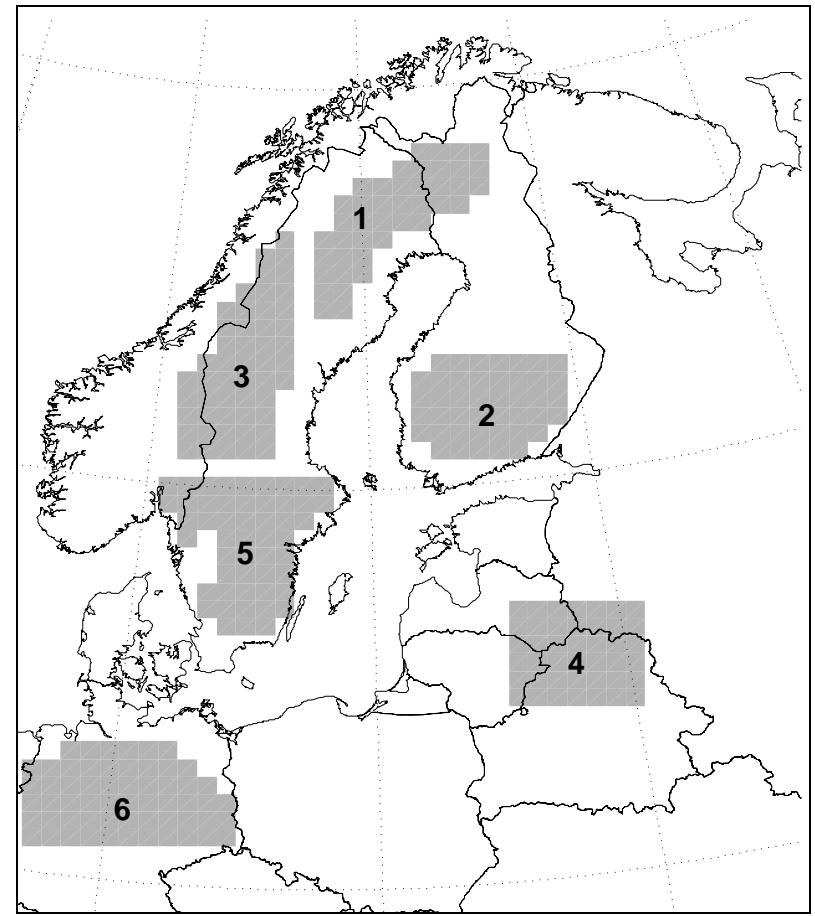

Fig. 2. Map of the six regions discussed in the text and as shown in Figs. 2-9. The regions were selected to cover different bio-climatic zones: the subarctic and boreo-montane zone (region 1), the boreal zone (regions 2 and 3), the boreo-nemoral zone (regions 4 and 5), and to the nemoral zone (region 6).

simulations, and how this source of uncertainty compares to the uncertainty related to differences in RCM formulation. Finally, to assess the projected climate change impact the three periods available in SBI/CHM RCA3_GCM ensembles were compared. Kjellström et al. (2011) provides a detailed analysis of the climate change signal in the ensemble.

In the evaluation of the SBI/CHM RCM-ERA40 ensembles we use the SBI/CHM E-Obs best estimate as a reference dataset. For the SBI/CHM RCA3_GCM ensemble we follow the standard procedure of using the RCA3_ERA40 run as the reference climate dataset for the period of 1961-1990. For the two future periods, the climate change signals were calculated as the deviations from the reference period 1961-1990 of each RCA3_GCM ensemble member. Thus, the RCA3ERA40 run is the common denominator for evaluating both datasets. For the sake of brevity we will omit "SBI" and "CHM" from the ensemble names in the following presentation whenever there is no risk of a mix-up with the ensembles of driving climate data.

Six regions were selected (Fig. 2) to provide detailed analysis of the variability within and between the different impact model runs, covering different aspects of climate change impacts on the risk of frost damage. The entire study area was selected to cover the main distribution area of Picea abies, which includes several bioclimatic zones (Ahti, 1968).
Region 1 (42 gridcells) represents the sub-artic and boreomontane biotic zone of northernmost Sweden and Finland. The boreal zone (dominated by needle-leaf forest) is represented by region 2 (43 gridcells in southern Finland) and region 3 (51 gridcells in Mid Sweden). The boreo-nemoral zone is covered by region 4 (42 gridcells in the Baltic countries and Belarus) and region 5 (51 gridcells in south Sweden). The nemoral zone (dominated by broadleaf forest) is represented by region 6 in northern Germany (58 gridcells). The regions were selected so that the individual gridcells show reasonably homogeneous results in the simulations. That is, most of the variation is due to inter-annual variability rather than intra-regional variations. For the regional analyses, data for all years in a period and gridcells within a region was lumped together. This means that the sample size, $n$, ranges from $1176-1740$ (i.e. from $28 \times 42$ to $30 \times 58$ ).

The variation within the RCA3_GCM ensemble was further analysed by calculating percentiles, using the full dataset (all years in each period, and all gridcells in each region). For each gridcell, years with no frost damage were assigned an artificially high "missing data" value. This gives percentiles that are directly comparable in temporal profiles and across regions and models, producing a truncated frequency distribution with the corresponding high percentiles missing.

The projected changes in frost risk magnitude were illustrated by maps of the RCA3_GCM ensemble for the periods of 2011-2040 and 2070-2097 in comparison with the reference period. All calculations were performed in MATLAB.

\section{Results}

\subsection{Climate conditions of the reference period 1961-1990}

There is a south to north gradient in the onset of the vegetation period, variable $a$ in Eq. (1) (Fig. 3). In Germany, the onset commonly occurs in January or February, and in northern Scandinavia the onset usually occurs at the end of May or beginning of June. The inter-annual variability is higher in the South than in the North, indicated in the boxplots by large boxes for region 6 and long whiskers for region 5. The whiskers in region 1 and 3 reach values above 180 (i.e. later than 1st of July), indicating the arctic and high altitude conditions. The calculated date for the start of the vegetation period is influenced by uncertainties associated with climate model data (Fig. 3). The SBI RCM_ERA40 and SBI RCA3_GCM ensemble averages are close to the SBI E-Obs best estimates in regions $1-5$. In region 6 , however, the SBI RCA3_GCM ensemble average is about 20 days earlier than the SBI E-Obs best estimate, thereby being close to the SBI E-Obs upper $95 \%$ confidence bound. (The upper confidence bound is towards the warmer end, meaning that the onset of the vegetation period occurs earlier in the year.) The bias is 


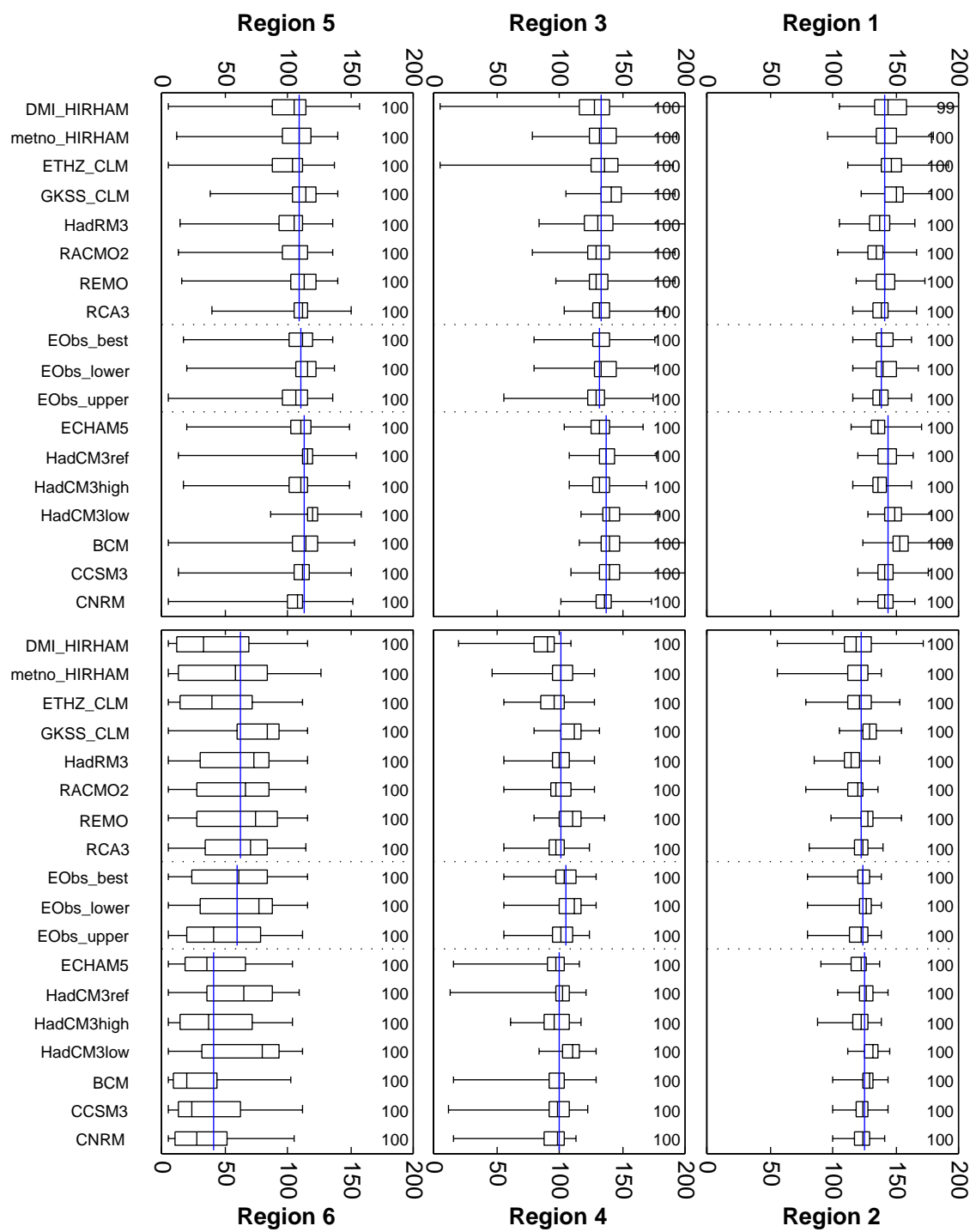

Fig. 3. Day number for onset of the vegetation period (variable $a$ in Eq. 1) simulated with the SBI model, driven by three different temperature datasets: (i) Eight RCM_ERA40 ensemble members (left part) for the reference period 1961-1990. (ii) E-Obs best estimate and the lower and upper 95\% confidence limits (middle part) for the reference period 1961-1990. (iii) Seven RCA3_GCM ensemble members (right) for the reference period 1961-1990. Data was analysed for the six regions, defined in Fig. 1. Each box (rectangle) extends from the lower to the upper quartile with the median indicated by the line in between. The whiskers extend to the minimum/maximum values. The horizontal lines across the boxes represent the average of the medians of the individual members of the three ensembles. The percentage (rounded to the nearest integer value) of years when the weather allows for an onset of the vegetation period is indicated above the boxes."

introduced by the GCMs, not the choice of RCM, as the corresponding RCA3_ERA40 median is about 10 days later than the E-Obs best estimate.

According to the spring backlash index, the nemoral zone (region 6) is the region with the highest risk for frost damage during the reference period (Fig. 4). In the other regions the frequency of spring backlashes is substantially lower. The two model ensembles do, however, generally indicate higher SBI values and a higher proportion of years with spring backlashes than simulations with the observed dataset (Fig. 4).
The cold hardiness model (CHM) provides a somewhat different picture of the risk of frost damage, as the geographical distribution of frost damage is more evenly spread among the regions (Fig. 5). The ensemble averages are rather close to zero, in accordance with the E-Obs simulations. Comparing the two ensembles (Figs. 4 and 5), the SBI/CHM RCM_ERA40 ensemble members have a larger spread and more extreme values than the SBI/CHM RCA3_GCM ensemble, indicating that the choice of RCM has a large influence on the results. 


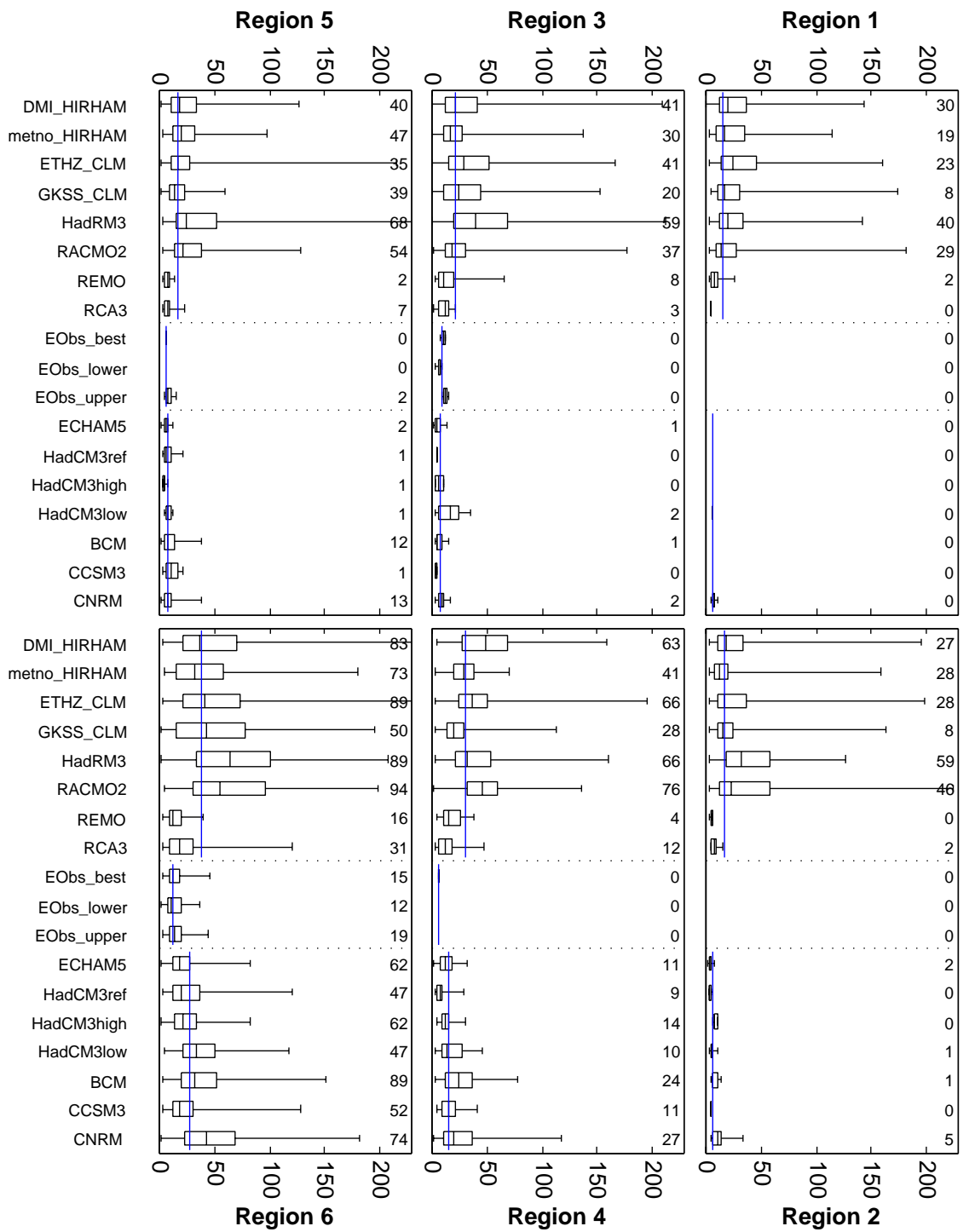

Fig. 4. Spring backlash index, units are degree-days. The organisation and layout of the graphs is the same as for Fig. 3 .

The impact of uncertainties associated with climate model data on the SBI estimates was quantified by comparing the SBI RCMERA40 ensemble members to the SBI E-Obs best estimate (Fig. 6a). For the onset of the vegetation period (Fig. 6a, top panel) no systematic bias across the ensemble members is indicated, but the spread between the ensemble members increase towards the south. A similar trend of increasing uncertainty toward the south is seen in E-Obs, though the sub-gridscale uncertainty in the observations, i.e. the E-Obs 95\% confidence interval is smaller than the RCM ensemble variability. For the three aspects of spring frost damage (SBI, number of frost events and minimum temperature), the E-Obs lower and E-Obs upper 95\% bounds produce almost the same result as the E-Obs best estimate. That is, the model is not very sensitive to small varia- tions in input data. All ensemble members show a systematic over-estimation of the spring backlash index, with 5 to 60 degree-days depending on RCM formulation (Fig. 6a, second panel). The RCM_ERA40 ensemble consistently overestimated the number of backlashes (Fig. 6a, third panel), increasingly more so in the southern and/or more maritime regions (at most with an average of 9 events). Consistent with this overestimation of the number of events is an underestimation of the minimum temperatures (Fig. 6a, bottom panel), i.e. too low temperatures during the most severe event, typically by $2{ }^{\circ} \mathrm{C}$ to $5{ }^{\circ} \mathrm{C}$. In general, models overestimating SBI consistently have too many events and a negative bias in minimum temperature. There is however one notable exception to this picture, GKSS-CLM_ERA40, which shows a strong positive bias both in the onset of the vegetation period 


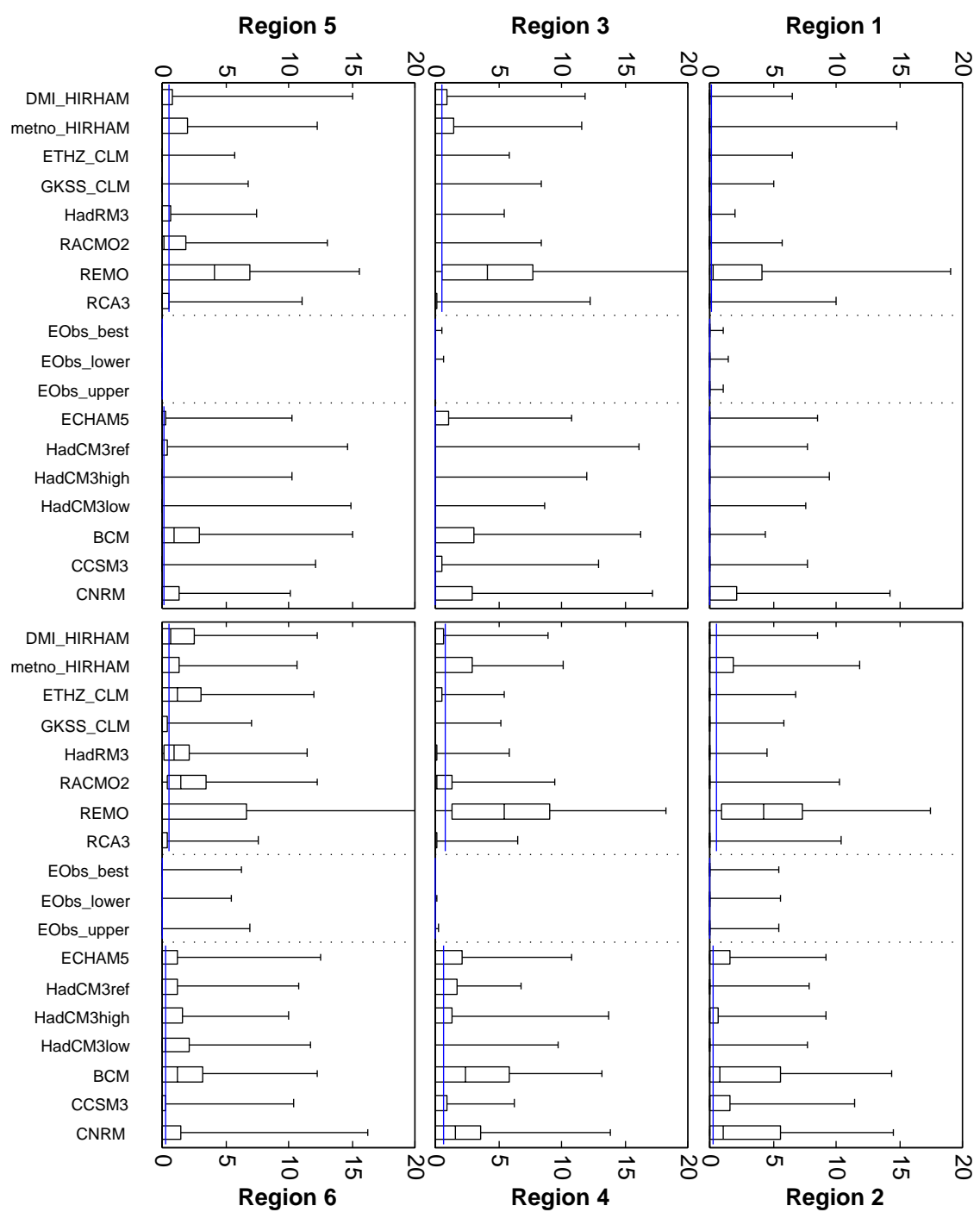

Fig. 5. CHM maximum frost damage during spring, units are degrees. The organisation and layout of the graphs is the same as for Fig. 3.

(late start) and SBI, yet a very small negative bias in number of events and even a small positive bias in minimum temperatures. We note that the deviations of the RCA3_ERA40 ensemble member are comparatively small for all four variables and in all six regions, thereby providing a good basis for assessing the climate change signal. We also stress that the SBI model has not been calibrated or adjusted to fit the RCA3 input data.

For the reference period, several RCA3_GCM ensemble members show a general tendency towards later onset of the vegetation period than the RCA3_ERA40, by up to 15 days (Fig. 6b). Region 6 is however different in that most models advance the onset of the vegetation period by about three to four weeks. Only the RCA3_ECHAM5, and to some extent RCA3_HadCM3high, shows a response that is consistent with the RCA3_ERA40 data. The bias in SBI is generally rather modest, in the range \pm 5 degree-days, somewhat more and generally negative in region 3 . But two ensemble members deviate from this general pattern, RCA3_BCM and RCA3_CNRM, that both show a strong positive bias (10-25 dd) in regions 4 and 6 . The ensemble members underestimate the number of frost events, generally by less than about 10 events, though three models stand out as having a positive bias of 15-20 events. This pattern is closely mirrored in the pattern of negative biases in minimum temperature. A general feature is that the spread in bias between different ensemble members grows towards the south.

We now turn to the CHM model estimates of frost damage. Several members of the CHM RCM_ERA40 ensemble underestimate the cold hardiness level, i.e. the autumn temperatures are too warm for obtaining deep cold tolerance (Fig. 7a top panel). For all members the bias decreases towards the south, even turning into a weak negative bias for some models. HadRM3_ERA40, and to some extent 
a)
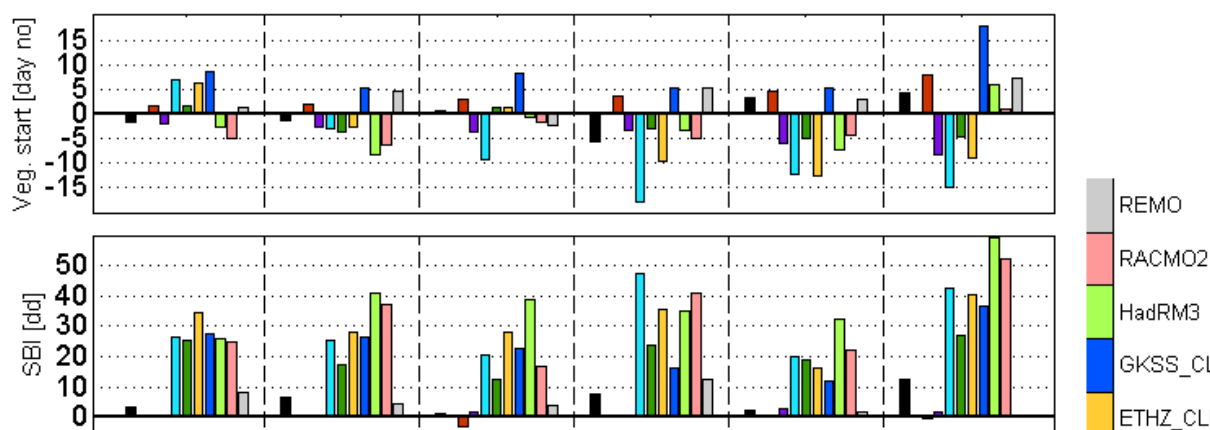

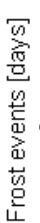

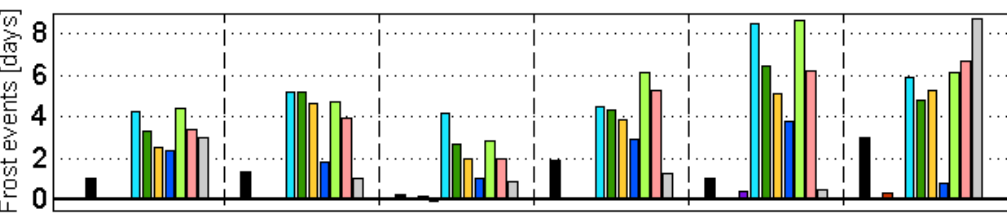

\section{ETHZ_CLM \\ METNO_HIRHAM}

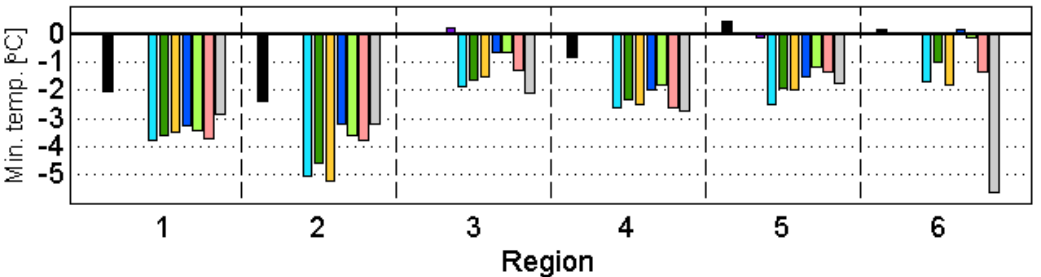

DMI_HIRHAM

EObs_max

EObs_min

EObs_best

RCA3

b)
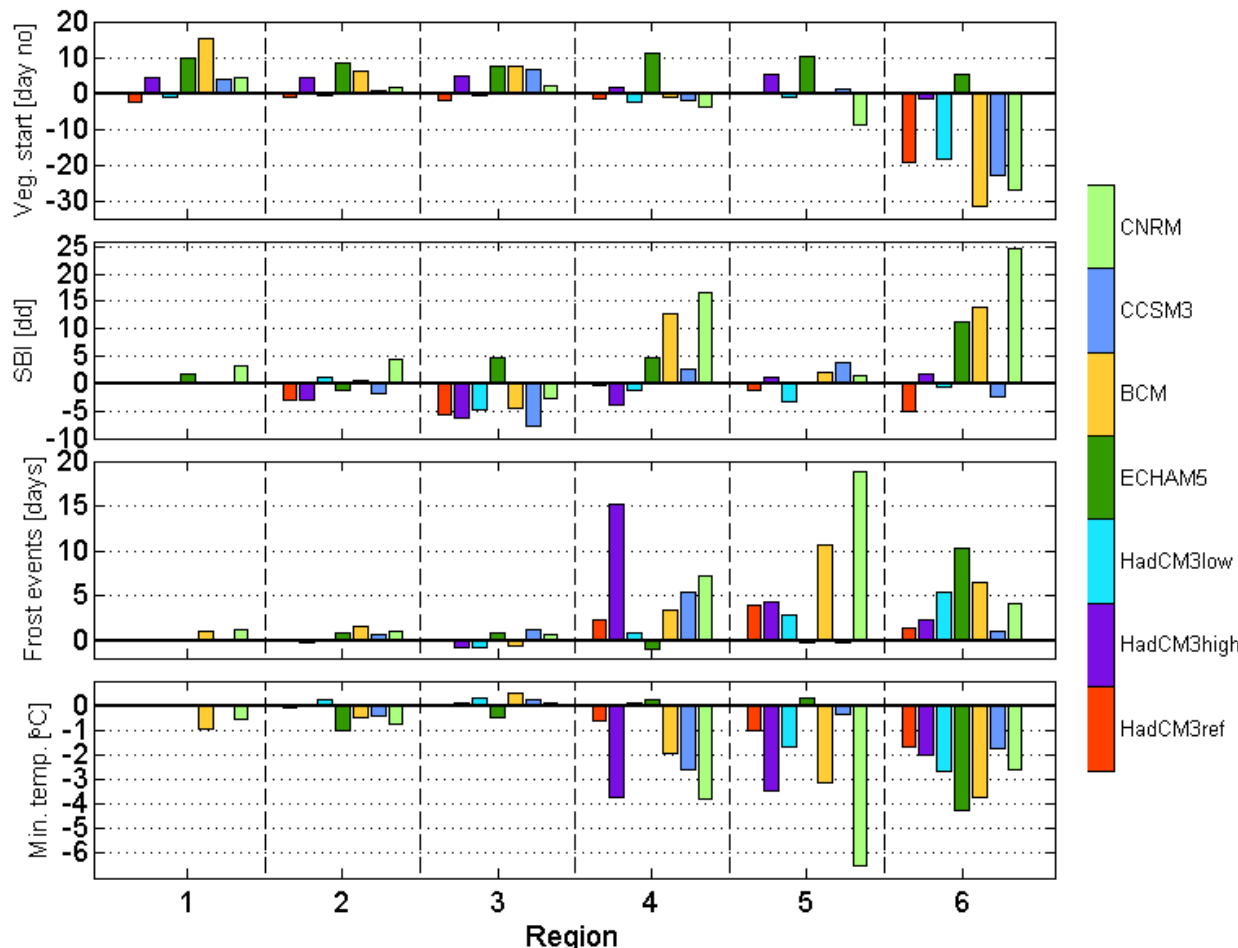

Fig. 6. Deviations from a reference value of the two SBI model comparisons: (a) spread among the RCM_ERA ensemble members (i.e. RCM_ERA minus E-Obs), (b) spread among the RCA3_GCM ensemble members during the control period (i.e. RCM_GCM 1961-1990 minus RCA3_ERA 1961-1990). The four panels of (a) and (b) show the different SBI model variables (cf. Table 1), from top to bottom: the onset of the vegetation period; SBI index; number of frost events; and minimum temperature during an event. 
a)
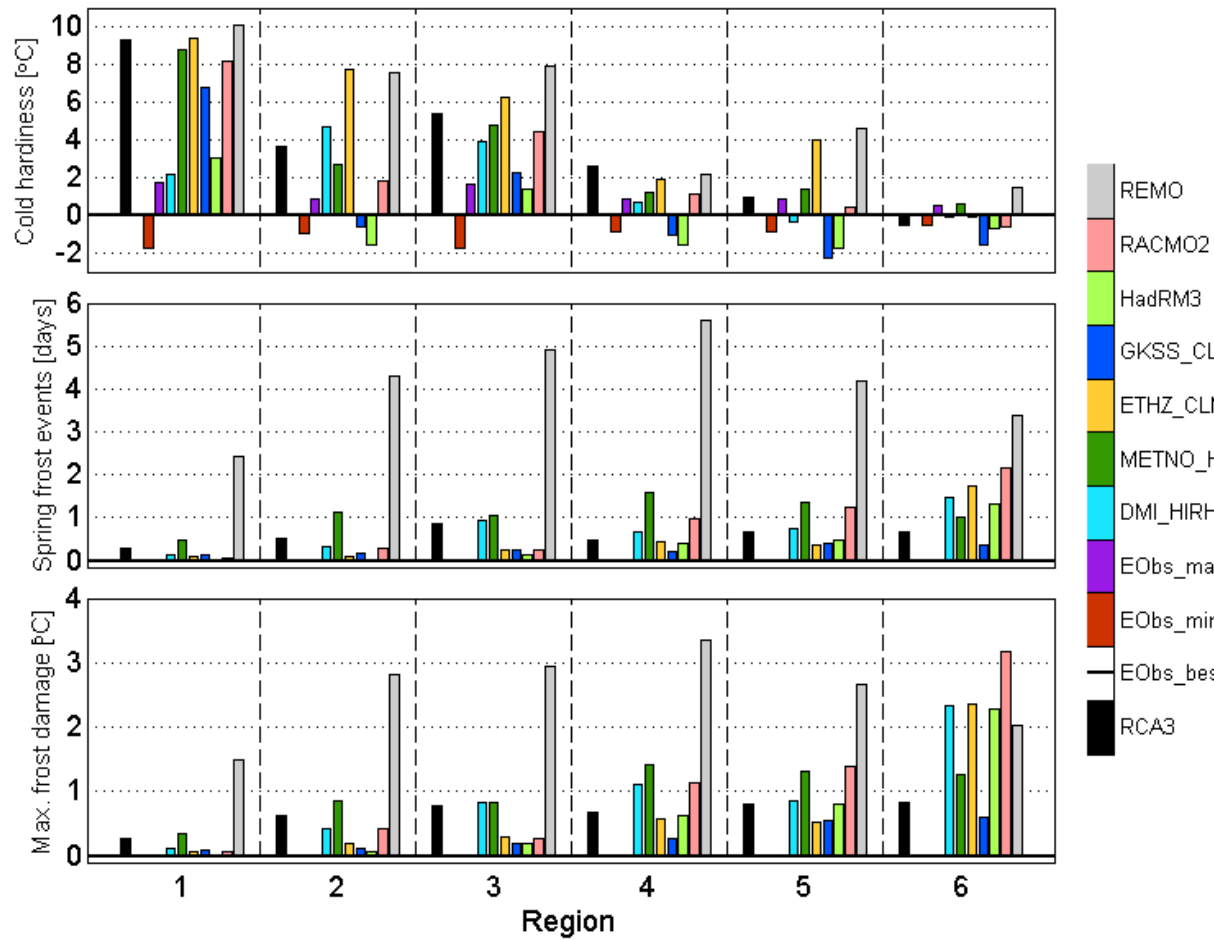

GKSS_CLM

ETHZ_CLM

METNO_HIRHAM

DMI_HIRHAM

EObs_max

EObs_min

-EObs_best

RCA3

b)
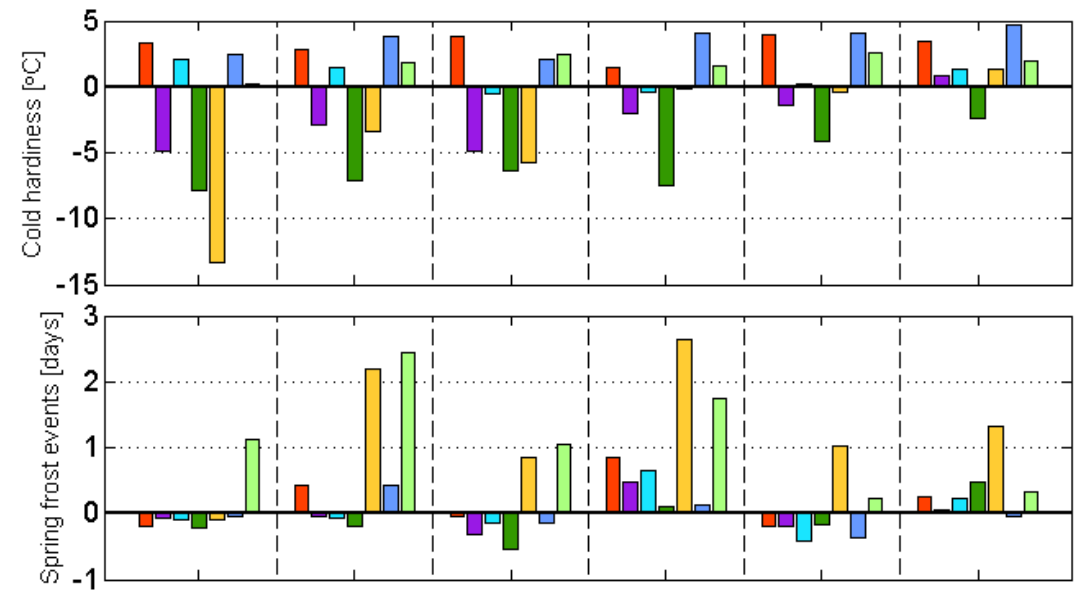

CNRM

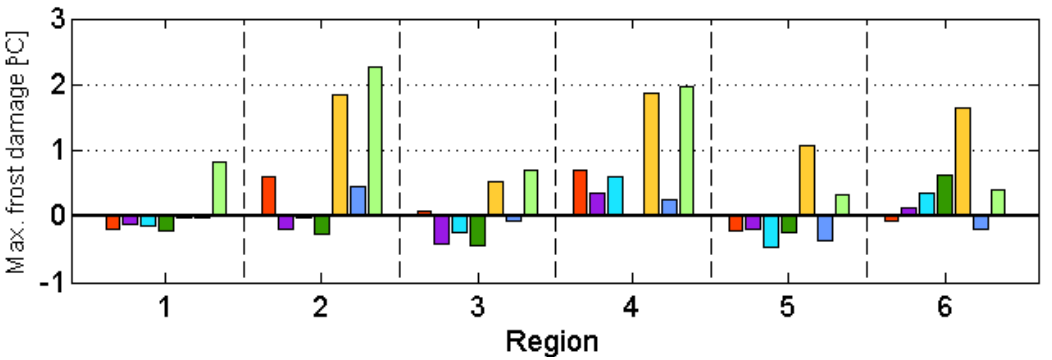

CCSM3

$\mathrm{BCM}$

ECHAM5

HadCM3low

HadCM3high

HadCM3ref

Fig. 7. Deviations from a reference value of the two CHM model comparisons: (a) spread among the RCM_ERA ensemble members (i.e. RCM_ERA minus E-Obs), (b) spread among the RCA3_GCM ensemble members during the control period (i.e. RCM_GCM 1961-90 minus RCA3_ERA 1961-1990). The three panels of (a) - (b) show the different CHM model variables (cf. Table 1), from top to bottom: number of cold hardiness level, spring frost events and maximum frost damage level. 


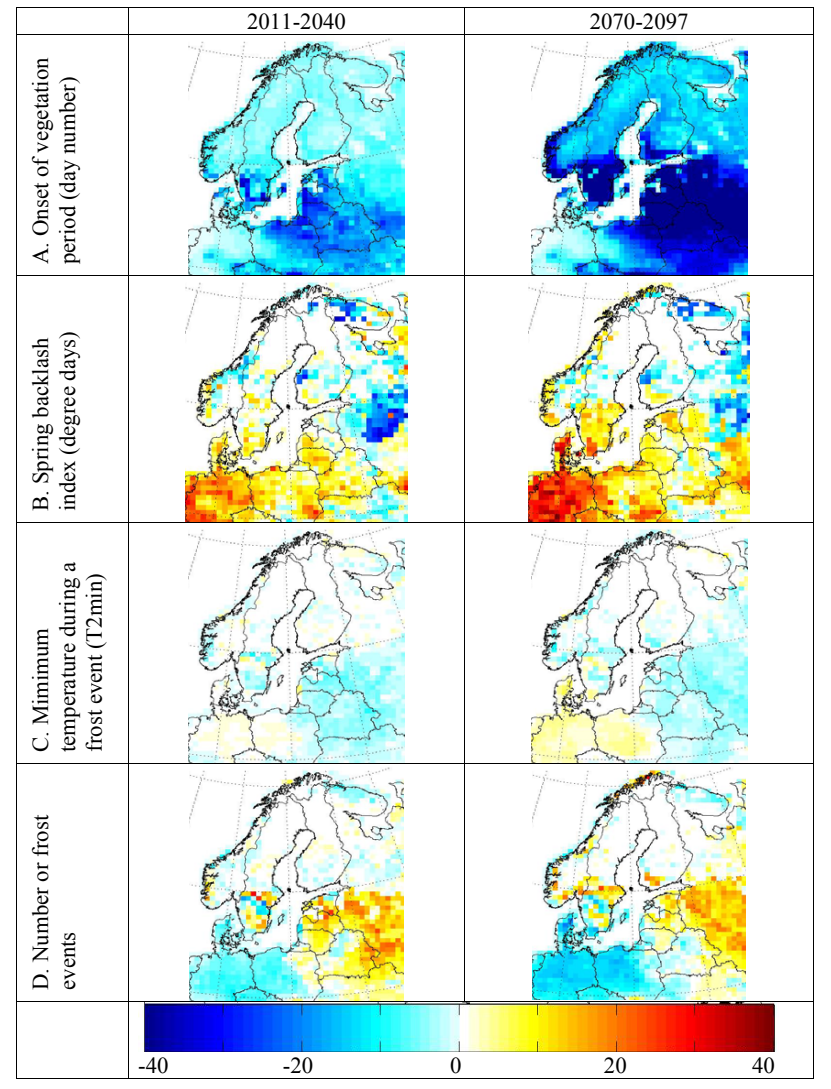

Fig. 8. The start of the vegetation period, together with the severity of spring backlashes, the number of frost events and the minimum freezing temperature, calculated using temperature data from RCA3 driven at the boundary conditions with output from an ensemble of seven GCM data sets as input to the spring backlash index. The change in the most severe events (i.e. $10 \%$ of the most harmful events), calculated for the time periods of 2011-2040 and 2070-2097 in comparison with 1961-1990.

DMI-HIRHAM_ERA40 generally exhibits a low bias in hardiness. The RCA3 ERA40 run is one of those showing a pronounced trend, from a positive bias of about $+10^{\circ} \mathrm{C}$ in the north to about $0^{\circ} \mathrm{C}$ in the south. The CHM RCM_ERA40 ensemble generally overestimates the number of frost events (0-3 events) and the maximum frost damage (in generally less than $2{ }^{\circ} \mathrm{C}$ ) (Fig. 7a middle and bottom panels). For these two measures the bias is generally more pronounce in the south than in the north, however, one ensemble member (REMO_ERA40) shows a large bias in all regions. In the reference period, the cold hardiness level of the RCA3_GCM ensemble (Fig. 7b, top panel), exhibits a negative bias in the northern regions. This indicates that the RCA3_GCM ensemble in one sense offsets the positive northern bias of RCA3, evident in the CHM RCA3_ERA40 run. RCA3_BCM and RCA3_CNRM indicate a higher number of frost events and more severe frost damage than the other ensemble members.

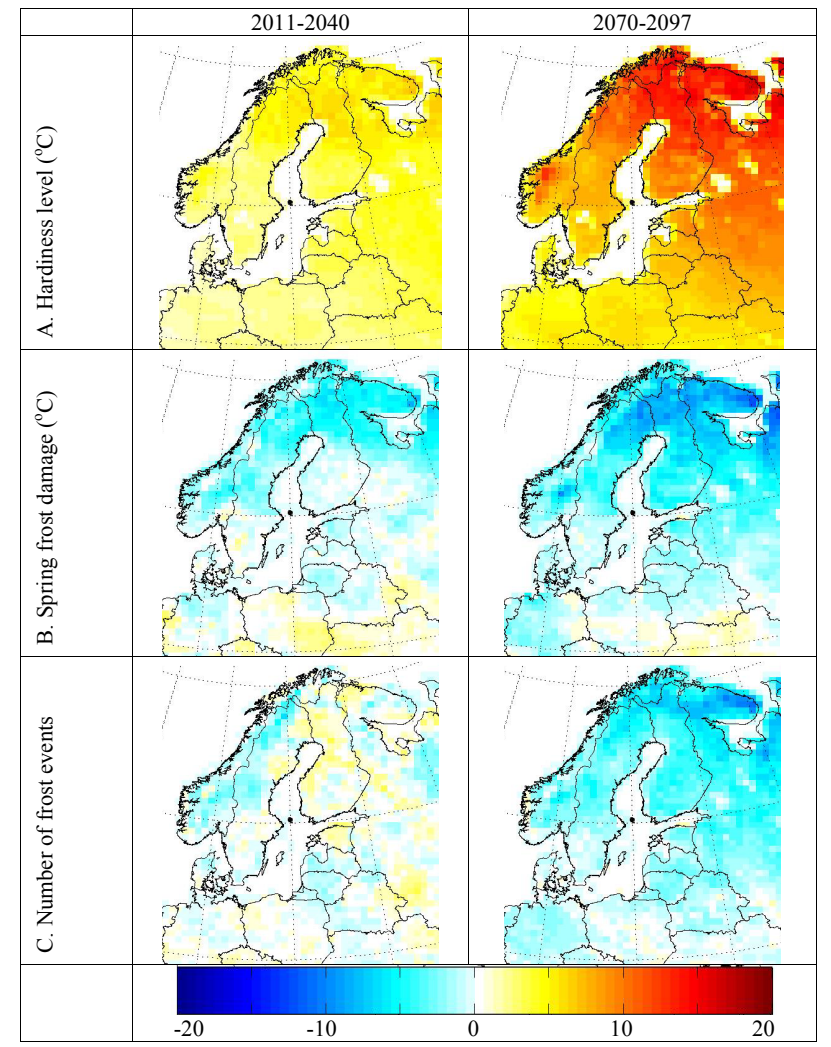

Fig. 9. The cold hardiness level, number of spring frost events, and the maximum frost damage, calculated using temperature data from RCA3 driven at the boundary conditions with output from an ensemble of seven GCM data sets as input to the cold hardiness model. The change of the RCA3_GCM ensemble members in the most severe events (i.e. $10 \%$ of the most harmful events), calculated for the time periods of 2011-2040 and 2070-2097 in comparison with 1961-1990.

\subsection{Future climatic conditions}

From a forest damage point of view it is not the average conditions that are problematic. Rather it is the rare extreme events that cause the most damage. The RCA3_GCM ensemble's average climate change signals of the more extreme events are outlined for study region, taking the different aspects covered by the SBI model (Fig. 8) and the CHM model (Fig. 9) into account. The spring backlash index indicates that the risk of frost events occurring during later spring phenological stages will increase in response to climate change in the nemoral zone, the south-western part of the study area (region 6, Fig. 8b). The risk decreases gradually towards the boreal zone in the north-eastern part. In the nemoral zone, very early springs cannot become any earlier than today (Fig. 8a), and the freezing temperatures will be closer to zero (Fig. 8c) and the number of frost events fewer (Fig. 8d). In the boreo-nemoral vegetation zone (regions 4 and 5), the 


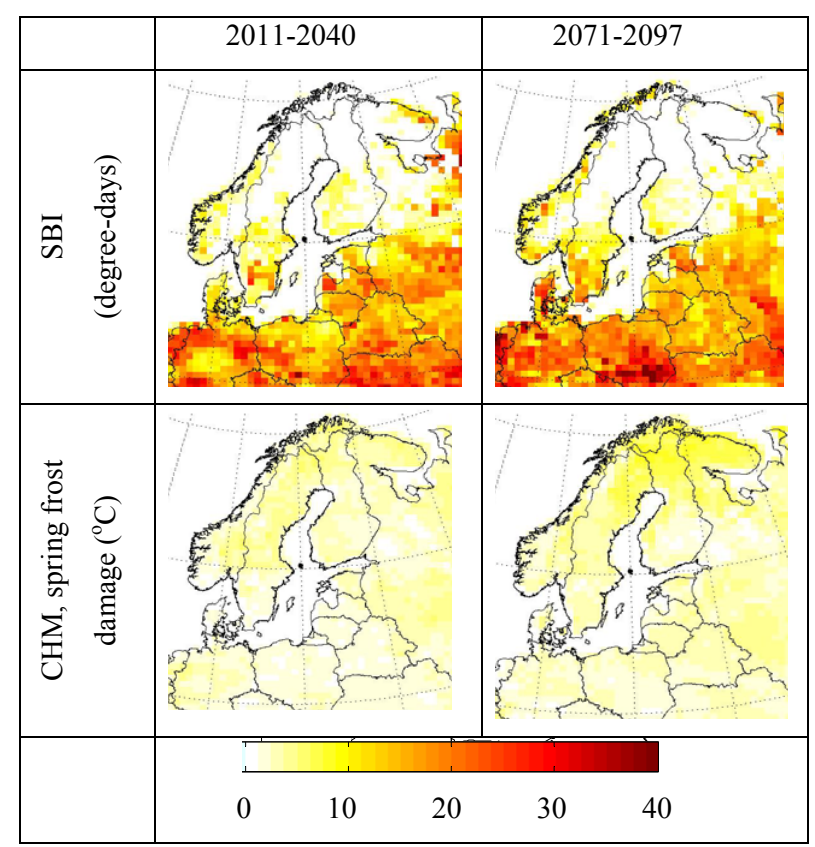

Fig. 10. The standard deviation of the projected SBI and the CHM maximum frost damage, calculated using temperature data from RCA3 driven at the boundary conditions with output from an ensemble of seven GCM data, calculated for the time periods of 20112040 and 2070-2097. Note that the two indices have different units, leading to different degrees of variability.

early springs will become progressively earlier in response to a warmer climate, which increases the risk of frost episodes with colder temperatures than before, along with an increased number of frost events. The projected changes for the different SBI model variables are insignificant for the boreal zone (region 2 and 3). The CHM indicate a somewhat different geographical pattern (Fig. 9). The maximum cold hardiness level (Fig. 9a) will decrease in response to a warmer climate, more so in the boreal zone than in the nemoral zone. The risk for spring frost damage (Fig. 9b) will increase in some parts of the nemoral zone, and decrease in the boreal zone (despite lower hardiness level). That is, the risk of frost damage is more related to the probability of sudden cold spells after the onset of dehardening, than by very cold events occurring in mid winter when the trees can tolerate low temperatures. In response to a warmer climate, regions with a more continental climate (regions 1,2 and 4) may experience a transient increase in the number of frost events (Fig. 9c), whereas regions with a coastal climate may only experience a reduction in the number of frost events.

The spread among ensemble members indicate that the model projections of future SBI are somewhat more pronounced in the nemoral zone than further north, while the uncertaties associated with the CHM spring frost damage is somewhat more pronounced in the boreal zone than further south (Fig. 10). For both indices, the uncertainties are some- what more pronounced during the later period (2071-2097) than for the near future (2011-2040).

To give a more complete picture of the climate change signal, we analyse how a range of percentiles, from $1 \%$ to 99\%, change over the three periods for each ensemble member (including all years in each period, and all gridcells in each region). Depending on the variable, the analysis is focused on either low or high percentiles (Figs. 11 and 12). The profiles for the onset of the vegetation period (Fig. 11a) show different characteristics for the different regions, being broadly similar for all ensemble members. In regions $1-3$, all percentiles for an ensemble member change by an approximately constant value, i.e. a shift in mean. Due to the fast transition (particularly in region (1) from winter to summer conditions, even a shift by 10-20 days results in the present day median condition becoming the future condition $90 \%$ 99\% (i.e. late onset dates). In the three southern regions, several low (early) percentiles show a drastic drop down to the beginning of the year. From Fig. $8 \mathrm{~b}$ it is clear that spring backlashes are not a common phenomenon because the limited sample size in all but region 6 (cf. Fig. 3) only allows a few (if any) of the nine percentiles to be computed. In region 6 there is a projected trend over time towards an increasing SBI (Fig. 11b), a decreasing number of spring backlashes (Fig. 11c) and higher minimum temperatures (Fig. 11d). The trends for the other regions are less consistent among ensemble members.

The CHM percentile profiles indicate a consistent decrease of the cold hardiness level across regions (Fig. 12a). Since the hardiness level is an integrated measure of daily temperatures, this is in line with the projected general warming. The number of spring frost events (Fig. 12b) shows an increasing trend from the period 1961-1990 to 2011-2040, and then a decrease to lower values further into the future (2070-2097). The spring frost events typically occur in about $10 \%$ to $25 \%$ of the cases (years and gridcells). The pattern of an initial upward trend followed by a negative trend is again seen in the maximum frost damage, though it is less consistent among ensemble members (Fig. 12c).

\section{Discussion}

The future projections in this study partly support the hypothesis that climatic warming can increase the risk of frost damage (Cannell and Smith, 1986). In a warmer climate, the onset of the vegetation period and dehardening in the nemoral and boreo-nemoral zone can occur earlier in season, at a time with slow seasonal progression and a high risk for temperature backlashes, increasing the risk for more extreme frost damage. Furthermore, the hardiness level of a tree depends on temperature-dependent physiological processes, and in a warmer climate, these processes may not reach the same hardiness levels as today. These extreme events can thus become more extreme, particularly in a relative sense when 

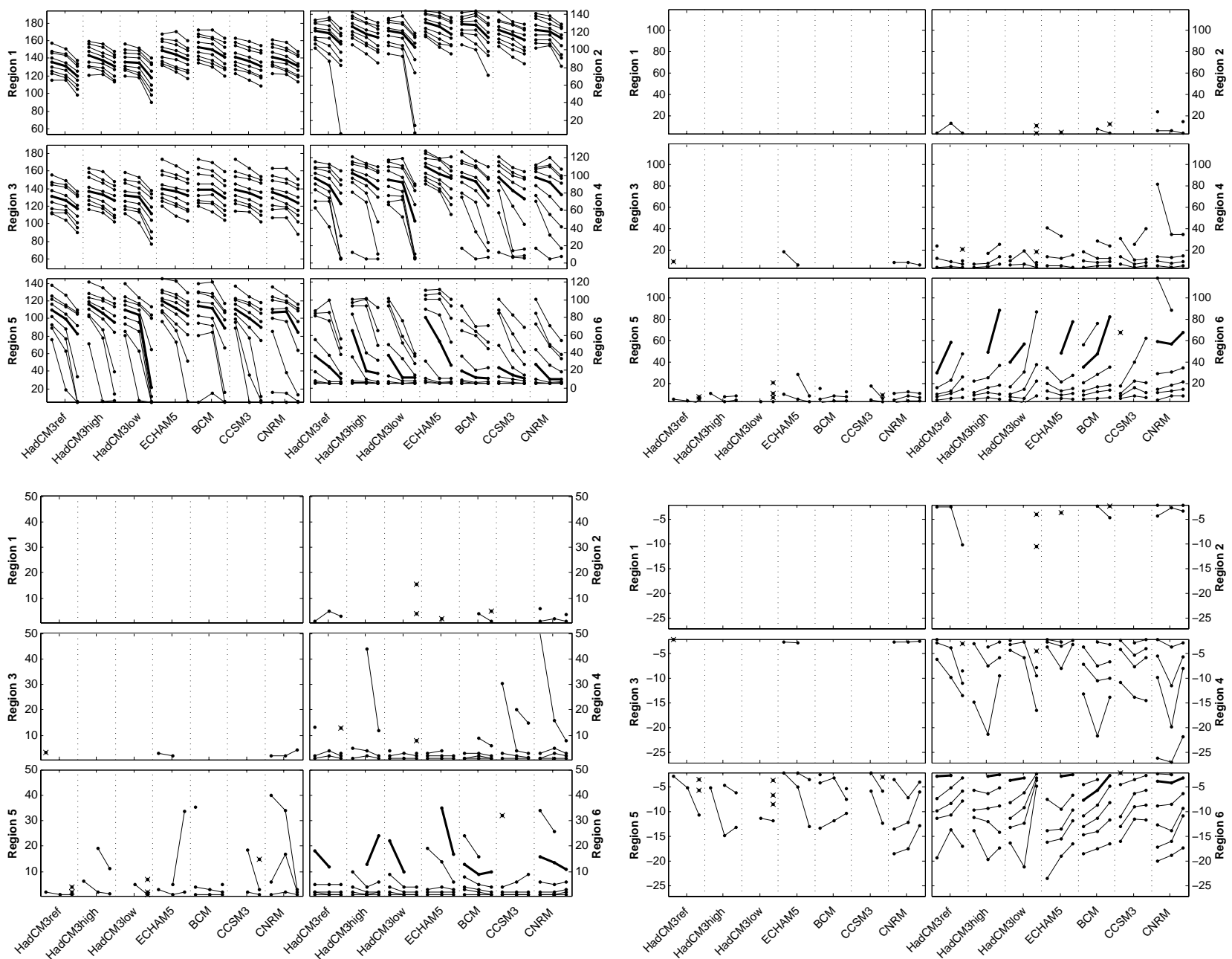

Fig. 11. Climate change profiles of the individual members of the SBI RCA3_GCM ensemble. (a) onset of the vegetation period, (b) the spring backlash index, (c) number of frost events, and (d) the minimum freezing temperature. The left end of each individual profile corresponds to the reference period 1961-1990, and the right end corresponds to the period 2070-2097. The "knee in the middle" corresponds to the intermediate period 2011-2040. Each region in Fig. 1 is shown in a separate panel, having the measure unit as y-axis and the driving GCM indicated in separate sections along the x-axis. Nine percentiles were calculated $(1 \%, 5 \%, 10 \%, 25 \%, 50 \%, 75 \%, 90 \%, 95 \%$ and 99\%) based on data for all gridcells in the region and all years in the period. If the measure was not given any value in some years, the corresponding percentiles were set to a missing value. If a percentile value could be calculated for one period only, it is shown as a cross. The $50 \%$ is highlighted by a thicker line.

the freezing temperature is related to a decreasing hardiness level. Even though the general trend may point towards a reduced risk of frost damage due to a warmer climate, one or very few frost damage events per 30 -year period is enough to cause a lasting negative effect on a forest stand, especially if the frost event occurs during the juvenile phase. Any increase in the risk of frost damage is, however, likely to be transient due to the fine balance between an increased risk of frost damage caused by earlier dehardening during a period when transient freezing temperatures are common and a decreased risk caused by warmer temperatures (Jönsson et al., 2004; Rammig et al., 2010).
By capturing different aspects of the risk of frost damage, the two impact models (SBI and CHM) account for some of the uncertainties associated with the model description of spring phenological process. The ensemble simulations with CHM and SBI have indicated the same general direction of change, although the climate change signal and associated uncertainties in the boreal zone were mainly detected by the CHM model. The SBI model indicates a somewhat lower risk of frost damage in the North than the CHM model due to the requirement for onset of the vegetation period $\left(4\right.$ consecutive days with T2mean $>+5{ }^{\circ} \mathrm{C}$ ). In the nemoral zone, the SBI indicate a somewhat higher risk of 

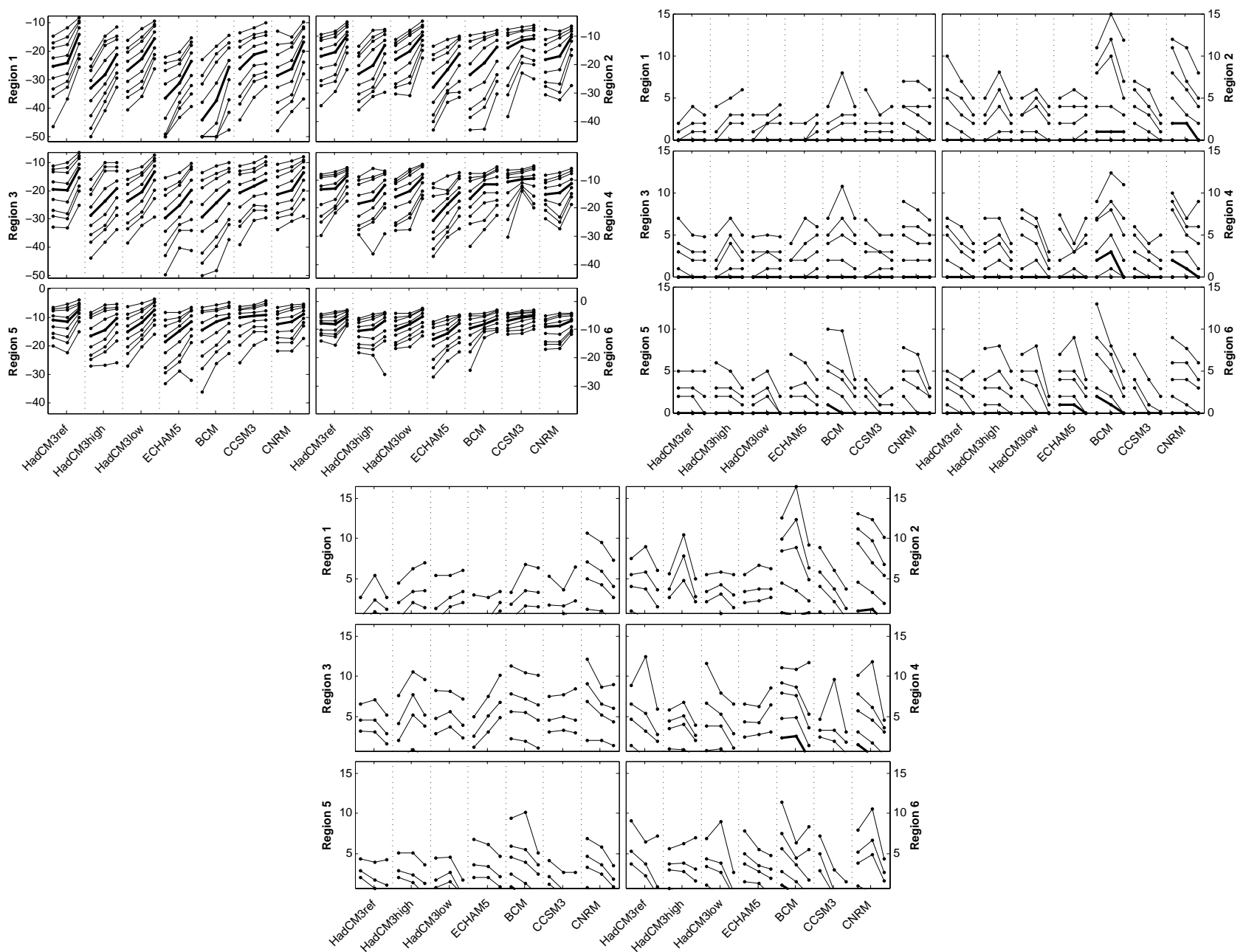

Fig. 12. Same as for Fig. 11 but for three CHM variables: (a) cold hardiness level, (b) number of spring frost events, and (c) the maximum frost damage. The $50 \%$ is highlighted by a thicker line.

frost damage as the SBI model does not account for cold periods allowing for rehardening in spring (Suni et al., 2003), whereas this is included in the CHM. Tree species that naturally occurring in the nemoral and boreal vegetation zones have the ability to adapt to seasonal changes in temperature, and can tolerate low temperatures during winter (Sakai and Larcher, 1987). However, when the trees start to deharden during spring, the sensitivity to sudden temperature backlashes increases because the rehardening processes are not fast enough to handle the large temperature drops associated with spring backlash events. Simultaneously, an early spring with periods of alternating hardening and dehardening may exhaust the storage of carbohydrates, rendering the trees even more sensitive to frost (Ögren et al., 1997; Öquist et al., 2001). Norway spruce is adapted to cold winters, and the nemoral zone having the highest risk for spring backlashes in current climate conditions is outside the natural distribution range, which can be approximated to the $-2{ }^{\circ} \mathrm{C}$ isotherm for the coldest winter month (Dahl, 1998).
The impact model simulations are influenced by climate modelling uncertainties and biases. Recent comparisons with RCM simulation ensembles (Jacob et al., 2007; Kjellström et al., 2007), indicated that the RCA3 temperature bias is in parity with the other ensemble members. For the winter period (October to March), the RCA3 ERA40 has a bias in the eastern, continental part of Europe by $+3{ }^{\circ} \mathrm{C}$ in the boreal zone and $+2{ }^{\circ} \mathrm{C}$ in the boreo-nemoral zone compared to ERA40 lateral forcing data (Kjellström et al., 2005, 2011). However, by running the two impact models with the three climate data ensembles, we were able to assess the specific influence on the SBI and CHM impact models. In general, the performance of the SBI/CHM RCA3_ERA40 run was close to the SBI/CHM E-Obs best estimate, and not in any case extreme compared to the other SBI/CHM RCM_ERA40 ensemble members (Fig. 3-5). Regarding the two spring frost damage variables, the SBI spring backlash index (Fig. 3) and in particular the CHM maximum frost damage (Fig. 4), all model based simulations overestimate the impact compared to the 
simulations based on the E-Obs gridded observations. This suggests that there is no simple relationship between temperature bias of an RCM and the corresponding bias in simulated frost damage impact. With respect to the RCA3_GCM ensemble, one possible explanation could be that the rather coarse resolution of the GCMs result in and exaggerated zonal flow bringing in too many cyclones over northern Europe, and too few blocking situations. This GCM bias in the large scale flow, which is inherited by the RCMs, may result in an underestimation of the hardening level driven by autumn cool/cold conditions, and an overestimation of the winter-/springtime day-to-day variability, thus increasing the probability of spring backlashes. However, also the RCM_ERA40, which is not affected by a positive zonal bias, exhibits a similar positive bias in the two frost damage variables. Thus, the sources of this bias have to be found elsewhere, and can well be model specific because widely different factors (e.g. clouds, snow cover, soil moisture) are influencing the temperature and its diurnal range in the spring. While it is beyond the scope of this study to analyse this in more detail, we note that our results serve to illustrate that climate model output analyses focusing on impacts may contribute towards identifying needs for improving RCM skill that are typically not found in the usual evaluation exercises.

This study is based on climate datasets with a spatial resolution of about $50 \times 50 \mathrm{~km}$. On this large scale we found that spring backlashes are rather infrequent, and the major factor behind a frost event will be determined by synoptic weather conditions. At the sub-gridcell scale, the local physiography is an important factor. As a consequence, spring frost damage may locally be frequent, even though the trees are genetically adapted to avoid the periods with a high risk of frost damage through winter hardening (Sutinen et al., 2001). The projected changes in risk of frost damage may have implications for forest production. Non-reversible frost damage can kill seedlings, and reversible frost damage requires high energy and water consumption for repair to occur, constraining the annual carbon gain and growth (Burton and Cumming, 1995; Kellomäki et al., 1995; Bergh et al., 1998; Man et al., 2009). Tree species with a more light-regulated spring phenology, such as oak and beech (Schaber and Badeck, 2003; Heide, 1993), could be an option to Norway spruce in regions with an increased risk for spring frost damage as they are less sensitive to temperature-induced dehardening. Further evaluation of climate impact and complex interactions among abiotic stressor and biotic response (Auclair et al., 1996; Nihlgård, 1997; Ayres and Lombardero, 2000), also including analysis of economical aspects, is required for assessing the impact of climate change on forest production and damage risk.

\section{Conclusions}

Future climate projections have indicated that extreme spring frost events can become more harmful in both the nemoral and boreo-nemoral forest zone, by occurring closer to budburst. Frost damage severity during extreme events may thus increase, even though the general trend of a warmer climate is moving towards a reduced frost risk. The implication of changes in frost risk for selection of plant material has to be evaluated from a species and variety- specific point of view. Changes in the number of frost events and in the minimum temperatures are important measures for characterizing the overall risk of damage. Besides providing specific results, impact model measures can contribute to the evaluation of RCM model performance by highlighting aspects typically not included in the usual evaluation exercises.

Acknowledgements. This study was financially supported by the EU-FP6 project ENSEMBLES (GOCE-CT-2003-505539). Additional funds for the modelling work were provided through the Swedish Mistra-SWECIA programme funded by Mistra (the Foundation for Strategic Environmental Research). Several of the RCA3 scenario ensemble simulations were done within the Nordic Climate and Energy Systems (CES) project. The RCA3 simulations were made on the climate computing resource Tornado and funded with a grant from the Knut and Alice Wallenberg foundation. The groups carrying out dynamical downscaling in ENSEMBLES (http://ensembles-eu.metoffice.com/) are kindly acknowledged, as is DMI for hosting the Ensembles RCM data archive. This work greatly benefitted from the ENSEMBLES E-Obs gridded observational climate dataset hosted by the ECA\&D project (http://eca.knmi.nl/ensembles).

Edited by: G. C. Leckebusch

Reviewed by: two anonymous referees

\section{References}

Ahti, T., Hämet-Ahti, L., and Jalas, J.: Vegetation zones and their sections in northwestern Europe, Annales Botanici Fennici, 5, 169-211, 1968.

Auclair, A. N. D., Lill, J. T., and Revenga, C.: The role of climate variability and global warming in the dieback of Northern Hardwoods, Water Air Soil Poll., 91, 163-186, 1996.

Augspurger, C. K.: Spring 2007 warmth and frost: phenology, damage and refoliation in a temperate deciduous forest, Funct. Ecol., 23, 1031-1039, 2009.

Ayres, M. P. and Lombardero, M. J.: Assessing the consequences of global change for forest disturbance from herbiovers and pathogens, Sci. Total Environ., 262, 263-286, 2000.

Bergh, J., McMurtrie, R. E., and Linder, S.: Climatic factors controlling the productivity of Norway spruce: A model-based analysis, Forest. Ecol. Manag., 110, 127-139, 1998.

Bergh, J., Freeman, M., Sigurdsson, B., Kellomäki, S., Laitinen, K., Niinisto, S., Peltola, H.. Linder, S. Modelling the short-term effects of climate change on the productivity of selected tree species in Nordic countries, Forest Ecol. Manag., 183, 327-340, 2003. 
Bleck, R., Rooth, C., Hu, D. M., and Smith, L. T.: Salinitydriven thermocline transients in a wind-forced and thermohalineforced isopycnic coordinate model of the north-atlantic, J. Phys. Oceanogr., 22, 1486-1505, 1992.

Böhm, U., Kücken, M., Ahrens, W., Block, A., Hauffe, D., Keuler, K., Rockel, B., and Will, A.: CLM - the climate version of LM: Brief description and long-term applications, COSMO Newsletter, 6, 225-235, http://www.cosmo-model.org/content/model/ documentation/newsLetters/newsLetter06/cnl6_clm.pdf, 2006.

Buonomo, E., Jones, R., Huntingford, C., and Hannaford, J.: On the robustness of changes in extreme precipitation over Europe from two high resolution climate change simulations, Q. J. Roy Meteor. Soc., 133, 65-81, 2007.

Burton, P. J. and Cumming, S. G.: Potential effects of climatic change on some western Canadian forests, based on phenological enhancements to a path model of forest succession, Water Air Soil Poll., 82, 401-414, 1995.

Cannell, M. G. R. and Smith, R. I.: Climate warming, spring budburst and frost damage on trees, J. Appl. Ecol., 23, 177-191, 1986.

Christensen, J. H., Christensen, O. B., Lopez, P., van Meijgaard, E., and Botzet, M.: The HIRHAM4 regional atmospheric climate model, DMI Scientific Report 96-4, 1996.

Christensen, J. H., Rummukainen, M., and Lenderink, G. (Editors): Formulation of very-high-resolution regional climate model ensembles for Europe. Met Office Hadley Centre, FitzRoy Road, Exeter EX1 3PB, UK., 160 pp., 2009.

Collins M., Booth B. B. B, Harris G. R., Murphy J. M., Sexton D. M. H., and Webb, M. J.: Towards quantifying uncertainty in transient climate change, Clim. Dynam., 27, 127-147, doi:10.1007/s00382-006-0121-0, 2006a.

Collins, W. D., Bitz, C. M., Blackmon, M. L., Bonan, G. B., Bretherton, C. S., Carton, J. A., Chang, P., Doney, S. C., Hack, J. J., Henderson, T. B., Kiehl, J. T., Large, W. G., McKenna, D. S., Santer, B. D., and Smith, R. D.: The Community Climate System Model version 3 (CCSM3), J. Climate, 19, 2122-2143, $2006 \mathrm{~b}$.

Dahl, E.: The phytogeography of northern Europe (British Isles, Fennoscandia and adjacent areas), Cambridge University Press, Cambridge, 297 pp., 1998.

Déqué, M., Dreveton, C., Braun, A., and Cariolle, D.: The Arpege/ifs atmosphere model - a contribution to the French community climate modelling, Clim. Dynam., 10, 249-266, 1994.

Eriksson, H.: Svenskt skogsbruk möter klimatförändringar. (Swedish forestry and climate change), Forest Agency Report 2007:8, 49 pp., 2007 (in Swedish).

Good, P., Bärring, L., Giannakopoulos, C., Holt, T., and Palutikof, J.: Non-linear regional relationships between climate extremes and annual mean temperatures in model projections for 19612099 over Europe, Clim. Res., 31, 19-34, 2006.

Gordon, C., Cooper, C., Senior, C. A., Banks, H., Gregory, J. M., Johns, T. C., Mitchell, J. F. B., and Wood, R. A.: The simulation of SST, sea ice extents and ocean heat transports in a version of the Hadley Centre coupled model without flux adjustments, Clim. Dynam., 16, 147-168, 2000.

Gutschick, V. P. and BassiriRad, H.: Extreme events as shaping physiology, ecology, and evolution of plants: toward a unified definition and evaluation of their consequences, New Phytol., 160, 21-42, 2003.

Hannerz, M.: Predicting the risk of frost occurrence after budburst of Norway spruce in Sweden, Silva Fenn, 28, 243-249, 1994.

Hänninen, H. and Kramer, K.: A framework for modelling the annual cycle of trees in boreal and temperate regions, Silva Fenn, 41, 167-205, 2007.

Hänninen, H., Beuker, E., Johnsen, Ø., Leinonen, I., Murray, M., Sheppard, L., and Skrøppa. T.: Impacts of climate change on cold hardiness of conifers, in: Conifer Cold Hardiness, edited by: Bigras, F. J. and Colombo, S. J., Kluwer Academic Publishers, Dordrecht, The Netherlands, 305-327, 2001.

Haugen, J. E. and Haakenstad, H.: Validation of HIRHAM version 2 with $50 \mathrm{~km}$ and $25 \mathrm{~km}$ resolution. RegClim General Technical Report No. 9., 159-173, 2006.

Haylock, M. R., Hofstra, N., Tank, A., Klok, E. J., Jones, P. D., and New, M.: A European daily high-resolution gridded data set of surface temperature and precipitation for 1950-2006, J. Geophys. Res.-Atmos., 113, D20119, doi:10.1029/2008JD010201, 2008.

Heide, O. M.: Dormancy release in beech buds (Fagus sylvatica) requires both chilling and long days, Physiol Plantarum, 89, 187191, 1993.

IPCC: Climate Change 2007: The Physical Science Basis. Contribution of Working Group I to the Fourth Assessment, in: Report of the Intergovernmental Panel on Climate Change, edited by: Solomon, S., Qin, D., Manning, M., Chen, Z., Marquis, M., Averyt, K. B., Tignor, M., and Miller, H. L., Cambridge University Press, Cambridge, United Kingdom and New York, NY, USA, 996 pp., 2007.

Jacob, D.: A note to the simulation of the annual and inter-annual variability of the water budget over the Baltic Sea drainage basin, Meteorol. Atmos. Phys., 77, 61-73, 2001.

Jacob, D., Andrae, U., Elgered, G., Fortelius, C., Graham, L. P., Jackson, S. D., Karstens, U., Koepken, C., Lindau, R., Podzun, R., Rockel, B., Rubel, F., Sass, H. B., Smith, R. N. D., Van den Hurk, B. J. J. M., and Yang, X.: A comprehensive model intercomparison study investigating the water budget during the BALTEX-PIDCAP period., Meteorol. Atmos. Phys., 77, 19-43, 2001.

Jacob, D., Bärring, L., Christensen, O.B., Christensen, J.H., Hagemann, S., Hirschi, M., Kjellström, E., Lenderink, G., Rockel, B., Schär, C., Seneviratne, S.I., Somot, S., van Ulden, A., and van den Hurk, B.: An inter-comparison of regional climate models for Europe: design of the experiments and model performance, Climatic Change, 81 Suppl. 1, 31-52, 2007.

Jönsson, A. M., Linderson, M. L., Stjernquist, I., Schlyter, P., and Bärring, L.: Climate change and the effect of temperature backlashes causing frost damage in Picea abies, Global Planet Change, 44, 195-207, 2004.

Jungclaus, J. H., Keenlyside, N., Botzet, M., Haak, H., Luo, J. J., Latif, M., Marotzke, J., Mikolajewicz, U., and Roeckner, E.: Ocean circulation and tropical variability in the coupled model ECHAM5/MPI-OM, J. Climate, 19, 3952-3972, 2006.

Kalberer, S. R., Wisniewski, M., and Arora, R.: Deacclimation and reacclimation of cold-hardy plants: Current understanding and emerging concepts, Plant Sci., 171, 3-16, 2006.

Kellomäki, S., Hänninen, H., and Kolström, M.: Computations on frost damage to Scots pine under climatic warming in boreal conditions, Ecol. Appl., 5, 42-52, 1995.

Kjellström, E., Bärring, L., Gollvik, S., Hansson, U., Jones, C., Samuelsson, P., Rummukainen, M., Ullerstig, A., Willén, U., and 
Wyser, K.: A 140-year simulation of European climate with the new version of the Rossby Centre regional atmospheric climate model (RCA3), Reports Meteorology and Climatology, No 108, Dec 2005, Swedish Meteorological and Hydrological Institute, SE-60176 Norrköping, Sweden, 54 pp., 2005.

Kjellström, E., Bärring, L., Jacob, D., Jones, R., Lenderink, G., and Schär, C.: Modelling daily temperature extremes: Recent climate and future changes over Europe, Climatic Change, 81 Suppl. 1. 249-265, 2007.

Kjellström, E., Nikulin, G., Hansson, U., Strandberg G., and Ullerstig, A.: 21st century changes in the European climate: uncertainties derived from an ensemble of regional climate model simulations, Tellus A, 63, 24-40, doi:10.1111/j.16000870.2010.00475.x, 2011.

Kozlowski, T. T. and Pallardy, S. G.: Acclimation and adaptive responses of woody plants to environmental stresses, Bot. Rev., 68, 270-334, 2002.

Kullman, L.: Tree-limit stress and disturbance - A 25-year survey of geoecological change in the Scandes mountains of Sweden, Geogr. Ann. A., 79A, 139-165, 1997.

Larsen, J. B.: Ecological stability of forests and sustainable silviculture, Forest. Ecol. Manag., 73, 85-96, 1995.

Lindergård, P.: Vinterklimatet och vårbakslag. (Winter climate and spring backlashes) Master thesis. Dept. of Physical Geography and Ecosystem Analysis. Lund University, Lund Sweden, 44 pp., 1996 (in Swedish).

Linkosalo, T., Hakkinen, R., Terhivuo, J., Tuomenvirta, H., and Hari, P.: The time series of flowering and leaf bud burst of boreal trees (1846-2005) support the direct temperature observations of climatic warming, Agric. For. Meteorol., 149, 453-461, doi:10.1016/j.agrformet.2008.09.006, 2009.

Man, R. Z., Kayahara, G. J., Dang, Q. L., and Rice, J. A.: A case of severe frost damage prior to budbreak in young conifers in Northeastern Ontario: Consequence of climate change?, For. Chron., 85, 453-462, 2009.

Menzel, A., Sparks, T. H., Estrella, N., Koch, E., Aasa, A., Ahas, R., Alm-Kubler, K., Bissolli, P., Braslavska, O., Briede, A., Chmielewski, F. M., Crepinsek, Z., Curnel, Y., Dahl, A., Defila, C., Donnelly, A., Filella, Y., Jatcza, K., Mage, F., Mestre, A., Nordli, O., Penuelas, J., Pirinen, P., Remisova, V., Scheifinger, H., Striz, M., Susnik, A., Van Vliet, A. J. H., Wielgolaski, F. E., Zach, S., and Zust, A.: European phenological response to climate change matches the warming pattern, Glob. Change Biol., 12, 1969-1976, 2006.

Myking, T.: Effects of constant and fluctuating temperature on time to budburst in Betula pubescens and its relation to bud respiration, Trees-Struct Funct., 12, 107-112, 1997.

Nakićenović, N. and Swart, R.: Emissions Scenarios, A Special Report of Working Group III of the Intergovernmental Panel on Climate Change, Cambridge Univ. Press., 612 pp., 2000.

Nihlgård, B.: Forest decline and environmental stress, in: The global environment; science, technology and management, edited by: Brune, D., Chapman, D. V., Gwynne, M. D., and Pacyna, J. M., Scandinavia Science, 422-440, Oslo. 1997.

Nikulin, G., Kjellström, E., Hansson, U., Strandberg, G., and Ullerstig, A.: Evaluation and future projections of temperature, precipitation and wind extremes over Europe in an ensemble of regional climate simulations, Tellus A, 63A, doi:10.1111/j.16000870.2010.00466.x, 2011.
Ögren, E., Nilsson, T., and Sundblad, L. G.: Relationship between respiratory depletion of sugars and loss of cold hardiness in coniferous seedlings over-wintering at raised temperatures: Indications of different sensitivities of spruce and pine, Plant Cell Environ., 20, 247-253, 1997.

Öquist, G. Gardeström, P., and Huner, N. P. A.: Metabolic changes during cold acclimation and subsequent freezing and thawing, in: Conifer Cold Hardiness, edited by: Bigras, F. J. and Colombo, S. J., Kluwer Academic Publishers, Dordrecht, The Netherlands, 137-163, 2001.

Partanen, J., Koski, V., and Hanninen, H.: Effects of photoperiod and temperature on the timing of bud burst in Norway spruce (Picea abies), Tree Physiol., 18, 811-816, 1998.

Rammig, A., Jönsson, A. M., Hickler, T., Smith, B., Bärring, L., and Sykes, M. T.: Impacts of changing frost regimes on Swedish forests: Incorporating cold hardiness in a regional ecosystem model, Ecol. Model. 221, 303-313, 2010.

Roeckner, E., Brokopf, R., Esch, M., Giorgetta, M., Hagemann, S., Kornblueh, L., Manzini, E., Schlese, U., and Schulzweida, U.: Sensitivity of simulated climate to horizontal and vertical resolution in the ECHAM5 atmosphere model, J. Climate, 19, 3771-3791, 2006.

Royer, J. F., Cariolle, D., Chauvin, F., Deque, M., Douville, H., Hua, R. M., Planton, S., Rascol, A., Ricard, J. L., Melia, D. S. Y., Sevault, F., Simon, P., Somot, S., Tyteca, S., Terray, L., and Valcke, S.: Simulation of climate changes during the 21 st century including stratospheric ozone, C. R. Geosci., 334, 147-154, 2002.

Sakai, A. and Larcher, W.: Frost survival of plants. Ecological studies vol 62. Berlin, Germany, Springer Verlag, 321 pp., 1987.

Samuelsson, P., Jones, C. G., Willén, U., Ullerstig, A., Gollvik, S., Hansson, U., Jansson, C., Kjellström, E., Nikulin, G., and Wyser, K.: The Rossby Centre regional climate model RCA3: Model description and performance, Tellus A, 63, 4-23, doi:10.1111/j.1600-0870.2010.00478.x, 2011.

Saxe, H., Cannell, M. G. R., Johnsen, B., Ryan, M. G., and Vourlitis, G.: Tree and forest functioning in response to global warming, New Phytol., 149, 369-399, 2001.

Schaber, J. and Badeck, F. W.: Physiology-based phenology models for forest tree species in Germany, Int. J. Biometeorol., 47, 193201, 2003.

Schär, C., Vidale, P. L., Lüthi, D., Frei, C., Häberli, C., Liniger, M. A., and Appenzeller, C.: The role of increasing temperature variability in European summer heatwaves, Nature, 427, 332336, 2004.

Sogaard, G., Johnsen, O., Nilsen, J., and Junttila, O.: Climatic control of bud burst in young seedlings of nine provenances of Norway spruce, Tree Physiol., 28, 311-320, 2008.

SOU: Sweden facing climate change - threats and opportunities, Swedish Government Official Report SOU 2007:60, Ministry of the Environment, Stockholm: Fritze, 679, 2007.

Suni, T., Berninger, F., Vesala, T., Markkanen, T., Hari, P., Makela, A., Ilvesniemi, H., Hanninen, H., Nikinmaa, E., Huttula, T., Laurila, T., Aurela, M., Grelle, A., Lindroth, A., Arneth, A., Shibistova, O., and Lloyd, J.: Air temperature triggers the recovery of evergreen boreal forest photosynthesis in spring, Global Change Biol., 9, 1410-1426, 2003.

Sutinen, M.-L., Arora, R., Wisniewski, M., Ashworth, E., Strimbeck, R., and Palta, J.: Mechanisms of frost survival and 
freeze-damage in nature, edited by: Bigras, F. J. and Colombo, S. J., in: Conifer Cold Hardiness, Kluwer Academic Publishers, Dordrecht, The Netherlands, 89-120, 2001.

Uppala, S. M., Kållberg, P. W., Simmons, A. J., Andrae, U., Bechtold, V. D., Fiorino, M., Gibson, J. K., Haseler, J., Hernandez, A., Kelly, G. A., Li, X., Onogi, K., Saarinen, S., Sokka, N., Allan, R. P., Andersson, E., Arpe, K., Balmaseda, M. A., Beljaars, A. C. M., Van De Berg, L., Bidlot, J., Bormann, N., Caires, S., Chevallier, F., Dethof, A., Dragosavac, M., Fisher, M., Fuentes, M., Hagemann, S., Holm, E., Hoskins, B. J., Isaksen, L., Janssen, P., Jenne, R., McNally, A. P., Mahfouf, J. F., Morcrette, J. J., Rayner, N. A., Saunders, R. W., Simon, P., Sterl, A., Trenberth, K. E., Untch, A., Vasiljevic, D., Viterbo, P., and Woollen, J.: The ERA-40 re-analysis, Q. J. Roy. Meteor. Soc., 131, 2961-3012, 2005. van Meijgaard, E., van Ulft, L. H., van de Berg, W. J., Bosveld, F. C., van den Hurk, B. J. J. M., Lenderink, G., and Siebesma, A. P.: The KNMI regional atmospheric climate model RACMO, version 2.1., Available from KNMI, Postbus 201, 3730 AE, De Bilt, The Netherlands. http://www.knmi.nl/bibliotheek/knmipubTR/ TR302.pdf, 43, 2008. 